\title{
On the General Secular Contradiction Secularization, Christianity, and Political Theology
}

\author{
A LEX DUBILET
}

The general omission of Karl Marx from contemporary discussions of political theology is surprising given that "On the Jewish Question" not only offers one of the first frontal critiques of the modern state, it does so through a resolutely political-theological prism. Significantly, the essay does not critique a particular form of the state in order to reconstruct it on some supposedly more legitimate basis. It seeks instead to delineate the presence of the theological within the political form and operations of the state as such. Marx does not confuse political theology with the question of the theological legitimation of politics, as though theology was merely a name for an external surplus; rather, he diagnoses the structural and historical interrelatedness of the two fields and their operations. In his elaboration of the essential analogies of theological and political concepts and operations, Marx partakes in political theology-but he does so by deforming its accepted coordinates, rejecting at once the liberal statist visions of modernity and any theological or quasi-theological critiques of that modernity that emerge from a bolstering of the structures (and strictures) of transcendence, in order to think outside the field structured by this duality across its various articulations. It is the danger of the resulting realignment, which has the power to redraw the entire problematic as well as the status, morphology, and significance of its central concepts, that renders Marx's exclusion understandable but also engenders the exigency to challenge it. What follows seeks to rectify this genealogical lacuna through an exploration of the transformations entailed by "On the Jewish Question" for po- 
litical theology as a discourse-an exploration that will reassess some of the discourse's foundational conceptual contours, including the significance of immanence and transcendence, the relation of Christianity to the secular state, and the link between mediation and sovereignty. Resisting the persistent counterposing of the Christian to the secular, it will instead reorient political theology around the drive for delegitimation and the abolition of the order of the world.

From certain perspectives, often liberal in inclination, the insights of political theology are reducible to the cunning deployments of theological supplements within the political, as in, for example, the state appealing to transcendent authority for its legitimation, sanctification, or grounding. ${ }^{1}$ To follow such a definition would, in turn, imply the critical necessity of displacing or exiting political theology by freeing the political from its contamination by religion and theology. The theological supplement would be merely a foreign element to be subtracted—or overcome with time-in order to perfect the freedom of the political. Were the question as simple as that, were it a question of a supplement, a transcendent theological legitimation, then Bruno Bauer, the target of Marx's critique, would be right: all that would be required to perfect the state would be to free it from its theological sanctifications. In fact, however, it is precisely at the moment of such subtraction that the power of the political-theological critique becomes truly necessary and operative.

Exiting from political theology is not nearly so easy to accomplish, because the logic of political theology_formulated by Carl Schmitt and earlier (and with a distinctly different aim) by Marx-is not that of the supplement but that of structural systematic analogy and historical transfer. The import of political theology lies in the diagnosis of a theological grammar operating at the heart of the secular state and of a more general transference of theological concepts into political ones. ${ }^{2}$ It is not a question of use or of legitimation, as much as of the secularized persistence of theological concepts and operations within the putatively secular state. Hence Schmitt's famous dictum: "All significant concepts of the modern theory of the state are secularized theological concepts not only because of their historical development . . but also because of their systematic structure." 3 Or, one might call to mind Jan Assmann's broader definition of political theology as encompassing not merely the secularization of theological concepts, but the more complex set of movements of secularization and theologization that inflect most of the fundamental concepts of Western modernity. ${ }^{4}$ Either way, the theological element is not external to the political, but internal to its operation of power. It marks not its contingent 
failure or incompletion, but the nature of its operation according to its concept and, as such, cannot be purified through subtraction or evolution. In other words, political theology is important as a problematic and a discourse not because it legitimates power transcendently, thereby necessitating secular critique-allowing for the self-satisfied restaging of Enlightenment's critique of religion-but precisely because it undercuts the triumphalist narrative of secularized modernity, disallowing its desires to dissociate and wash its hands of Christianity and enter into a world of secular self-legitimation. ${ }^{5}$

This is at the heart of Marx's response to Bauer's critique of the limitations inherent to the so-called Christian state, which for Marx is precisely "the imperfect state and Christianity serves as supplement and sanctification of this imperfection." 6 The critical task that Marx bequeaths is more complicated than simply the affirmation of a secular politics of the modern state against its theological distortions. Hence Marx's dialectical formula: "The perfected Christian state is not the so-called Christian state which recognizes Christianity as its foundation, as the state religion, and which therefore excludes other religions. The perfected Christian state is rather the atheist state, the democratic state, the state which relegates religion to the level of other elements of civil society" (222). In other words, it is the state as such, one that is no longer grounded through a theological supplement, that is the ultimately Christian one, in the sense that it fundamentally operates, as I will show shortly, according to the diremptive logic of Christianity. The conceptual operations of Christianity are not overcome into the neutrality of the state, rather the power of Christianity is exercised in and by the secular state when it operates according to its very concept and power. ${ }^{7}$

Exiting from the apparatus of political theology, according to this diagnosis, entails not merely moving beyond theology into the brave new world of pure politics, into the secular human order freed of all illusions, but the subversion of the conceptual analogy and transference of operations that structures and co-imbricates the theological and the political. The fundamental question is neither a theological legitimation of politics nor the formation of purely secular political realm, but the critical tracing of a complex morphology and the interleafing exchange of concepts that prevents theology and secular thought from being separated out into distinct containers and played off each other. This is the power of Marx's insistence that "The so-called Christian state is the Christian negation of the state, but is certainly not the political realization of Christianity" (222). The political realization of Christianity, by contrast, is found in the purely secular state: Christianity operates as religion as well as the name for the 
political form of modernity itself. In his own way, Marx here prefigures a claim articulated recently by Gil Anidjar, that secularism is the name Christianity gives itself in modernity, one of the ways "by which Christianity forgot and forgave itself" and rendered itself invisible and neutral. ${ }^{8}$

As has been frequently explored, the critique of the limits of political emancipation - the attainment of the equal rights and equal standing before the state-is at the heart of Marx's essay. ${ }^{9}$ Marx suggest that we examine political emancipation critically, since it always and necessarily remains merely political and ideal; but he does so also for another reason. Political emancipation marks also the emancipation of the political itself-a process through which the political separates itself from and disburdens itself of material life, establishing itself as an autonomous realm, coinciding with the state. The state creates its subject-citizens in the very same gesture in which it emancipates itself from the material elements that make up the life of those individuals, elements that now become permanently consigned to civil society. It is rendered an autonomous and pure sphere by making everything else count as merely "non-political distinctions" of civil society (219). The autonomy of the political and its concentration in the state is an act of purification that allows it to stand above the nowdepoliticized material life, which is not abolished in the process but is instead rendered a presupposition for the state. The result is a universality of "the standpoint of the state" (Staatsgesichtspunkt) standing above all the spheres of material life that it has relegated to civil society as apolitical, of merely private concern (219).

This critique of the political, of its purification and genesis, is revealed as a political-theological critique at the moment when the structure so enacted is shown to be a secularization — and a fulfillment—of Christianity. The very relation of state to civil society carries a genetic and structural analogy within it: "Where the political state has attained its full degree of development man leads a double life, a life in heaven and a life on earth, not only in his mind, in his consciousness, but in reality" (220). As secular, the state in fact enacts a double life, whose diremption carries a direct trace of secularization. The theological grammar of the celestial and the terrestrial, "a life in heaven and a life on earth" (220), is secularized and materialized into the grammar of the state and civil society. This secularization preserves the form and logic while enacting a displacement of site and register, by means of which the theological is divested of the substantive need to justify and defend itself. For Marx, this secularization marks not the decline but rather the genuine realization of Christianity, by which the theological diremption is rendered into one that actually structures real 
lived experience. The modern state is the worldly truth of Christianity and not its radical overcoming. It materializes a theological transcendence in the secular, or as Marx formulates it: "The so-called Christian state needs the Christian religion to complete itself as a state. The democratic state, the true state, does not need religion for its completion. On the contrary, it can discard religion [von der Religion abstrahiren] because in it the human foundation of religion is realized in a secular [weltliche] way" (223).

To say that the secular state realizes Christianity is not to embrace the West by taking up secularization as a uniting thread that constitutes it. ${ }^{10}$ Rather, it is to insist that it is not enough to affirm secularism to break with Christianity, just as, in contrast, it is insufficient to reaffirm Christianity to break with secularism. In other words, Marx's move is to avow that the central operation of secular power is not purely secular but, through a set of complex transferences and mutations, a secularized Christian one: "The final form of the Christian state is one which recognizes itself as state and disregards the religion of its members" (226). The modern state is not a break with Christianity, but a transmutation of Christianity-its very political realization-into a purely political and self-declared neutral and impartial space. It is precisely through the production of this neutral space, which insofar as it is neutral is also unmarked and invisible, that the secular state is, paradoxically, "the practical expression of [Christianity's] universal religious significance" (226).

Is there not, however, something fundamentally mistaken in such a political theological approach to Marx? After all, Marx's methodological insistence seems clear enough: "We do no turn secular questions into theological questions. We turn theological questions into secular questions" (217). Despite appearances, this is hardly a call for a worldly, secular criticism. Rather than rendering theology immaterial, what Marx suggests is that theological questions in modernity always have to be analyzed within the ambit of secular power. We fundamentally mistake the way secular power works if we take "religion" in modernity as offering the appropriate or sufficient object of polemic, rather than indicating something that is repeatedly produced and reproduced as an object and a problem by the state, its powers of sovereignty and mediation, its morphological relation to the life of civil society. In other words, all theoretical investments in or cathexes on religion are cases of mistaken displacement that render invisible the more foundational dialectics of secular state power in which they materially participate. "The contradiction in which the adherent of a particular religion finds himself in relation to his citizenship is only one aspect of the general secular contradiction between the political state and 
civil society" (226). The Jewish question-as other questions of religious difference-is produced as a question, as a problem, by the dominant epistemic regime of secular state power that incessantly engenders a depoliticized private sphere of civil society, while seeing it as a problem requiring regulation and management. ${ }^{11}$ To fixate on religion, or religious difference, as an obstacle to freedom, as Bauer or contemporary defenders of secularism do, is to fall into a fundamental inversion, mistaking an effect for a cause and failing to grapple with the general secular contradiction. For religion as a distinct object and problem is produced and reproduced in modernity by the secular state apparatus: being relegated to civil society by the state, it is forced to fit into the criteria of the normative category of religion entailed by the modern regime of secular power-relegated to the private sphere, depoliticized, centered on belief, lodged into the interiority of the subject, and so on. ${ }^{12}$ In insisting that critique remains theological when it fails to be posed correctly, Marx was the first to insist on the primacy of the secular state as the dominant politico-epistemic framework in which religion and religious difference become formulated, managed, and reproduced. This is what is entailed in turning theological questions into secular ones.

As Marx notes, using the case of the United States, complete political emancipation leads not to the abolition of religion, but to its vigorous flourishing, which occurs as religion is "relegated to the level of private interest" and becomes "a private whim, a caprice" (221-222). Insofar as political emancipation entails the elevation of the state above material liferendering it apolitical, something presupposed and to be managed-it also produces the modern concept of religion and its lived, materialized reality. Marx was one of the first to arrive at the truth that religion as a privatized phenomenon centered on belief is an effect of secular political modernity, one of the byproducts of the formation of the modern state. ${ }^{13}$ As such, rather than subscribing to the modern concept of religion, Marx should be seen as critically delineating its logic and elaborating a genealogy of its formation. ${ }^{14}$ Indeed, turning theological questions into secular ones requires inserting them into broader analytics of secular power and exploring the ways in which secular power produces religion and allows it to flourish-offering it up as a reified target for polemic and critique, while dissimulating its own primacy and productivity. This is the power of Marx's insistence to "no longer see religion as the basis but simply as a phenomenon of secular narrowness" (217).

According to Talal Asad's definition of secularism as a political doctrine and the secular as an epistemic category that undergirds its assumptions and sensibilities, ${ }^{15}$ not only is Marx not a secular thinker, it is the position 
of secularism that he fundamentally targets in his polemic with Bauer, who poses the conceptual logic of secularism as the ideal horizon. For Bauer, the religious opposition between Jews and Christians is a problem that is to be overcome through recourse to a properly secular state: religious difference is a material difference that must be overcome into the universality of citizenship. This proposal is precisely the project of secularism, the restructuring of the subject and its allegiances within a nation-state paradigm. It declares that it is necessary to renounce religion as a special marker, as a marker of substantial difference, in order to be emancipated as citizens and members of civil society, of the civil life of the world, and to inhabit the liberal secular dream of a neutral space. By contrast, Marx's political theological reflections reject such a secularist distribution of concepts in order to confront Christianity's mutations through which it persists and is fully realized in the putatively secular life of the state. One might say that if theological criticism has to become secular criticism, then secular criticism has to be apprehended as political theological criticism, otherwise it fails to trace the transmuted persistence of Christianity in the political form of the state. In other words, because Christianity spans across the theologico-political morphological divide, it cannot be posed as exclusively a theological question, but must be posed as a political theological one-thereby disallowing all narration that would affirm the purified life of the secular freed from its links with Christianity. ${ }^{16}$

Therefore, Marx's quip that when "the question ceases to be theological, Bauer's criticism ceases to be critical" is hardly a call for a worldly, secular criticism (217). This would be to underestimate and misjudge the nature, scope, ontology, and operation of secular power. Indeed, the secularist argument morphologically reenacts the Christian operation that requires the conversion of the other toward a true religion: in both cases a (Jewish) remainder is seen as a culprit for unattained and incomplete universality. The state project of a universality that abstracts from difference is a mutation and persistence of a Christian project, wherein the material difference deemed religious is seen as a resistant remainder that must be overcome. In this schema, religious difference always doubles as historical difference, which, in this case, positions the Jews in particular as the backward remainder to a universalized history of mankind. In short, secular modernity retains the Christian structure of supersessionism. Indeed, the concrete power, persistent to this day, of Marx's question becomes obvious if this demand is seen as a broader instigation: "If you [Jews, but also Muslims] want to be politically emancipated without emancipating yourselves as humans, the incompleteness and the contradiction lies not in you but in the nature and the category of political emancipation" (226). ${ }^{17}$ 
For Marx, secular power works as a multifaceted apparatus of transcendent mediation generated by the general secular contradiction between civil society and the state. ${ }^{18}$ But this secular contradiction enacts and materializes a structure of diremption, of the double life, originally articulated in a theological form in Christianity. With this diagnosis, Marx places the operation of mediation at the heart of the political theological problematic. "The state is the mediator [Mittler] between man and man's freedom. Just as Christ is the mediator to whom man attributes all his divinity, all his religious bonds, so the state is the mediator to which man transfers all his non-divinity, all his human freedom" (219; trans. modified). Here, Marx is concerned not with the way religion is constituted as a merely private affair under secular power but rather with the way religion-less as a generic category than as a second name for Christianity-operates as an apparatus of transcendence, diremption, and mediation that is secularized and persists in the form of the secular state. Religion in this case names not merely what is delimited and lodged within one side of the general secular contradiction (i.e., within civil society) but rather, in a way, the entire diremptive logic underlying the general secular contradiction.

At the heart of mediation for Marx is the exception — not the sovereign state of exception that suspends the law as a way to uphold it against the perceived threat of antinomian chaos but the exceptional apparatus of secularized eucharistic mediation. To understand how the exception operates, it is useful to turn to another of Marx's judgments: "Man in his immediate reality, in civil society, is a profane being" (220). Despite all its apparent immediacy, this figure of man is not a natural being but an "illusory phenomenon," a product of the secularized structure of diremption. It indicates the materialized terrestrial life severed not only from the celestial heavenly life but also from all that is not private, individuated, or appropriated, from all that is common, from what Marx terms species being. In fact, we might say that if the secular is the entire structure of diremption, the immediate reality, the earthly part of the secular contradiction is the profane. But this profane life does participate in the common life, in the secularized celestial life in the state: for the member of civil society, for the bourgeois, as Marx writes, "life in the state is nothing more than an appearance or a momentary exception" (220). Marx is here redeploying Bauer's words, but does so while replacing the subject-it is no longer the figure of the Jew, as the remainder to the universal, that lives or participates as an exception, but the figure of the bourgeois, the generic member of civil society (220). In other words, the exception is political life itself, which temporarily suspends the primacy of private (and privative) life, a kind of communion with the communal in excess of the 
"profane being" that makes up its (illusory, but actual) existence in civil society.

This secularized model of exceptional participation in the celestial community ultimately upholds life as fundamentally dirempted. "The sovereignty of man — but of man as an alien being distinct from actual man-is the fantasy, the dream, the postulate of Christianity, whereas in democracy it is a present and material reality, a secular maxim" (226). The Christian dream, along with the apparatus of external mediation that binds the earthly and the transcendent aspects of life, is secularized and actualized in the structure of modernity. But of course, the sovereignty this exception generates is a "fictitious sovereignty," as Marx writes, "divested of his real individual life and filled with an unreal universality" (220). So, the structure of mediational exception suspends the profane being, but does not abolish it, does not dissolve the structure that generates it. Rather, it temporarily suspends it only in order to perpetuate what it suspends all the more.

Mediational exception justifies itself by posing profane being and the state of diremption as natural and ineluctable_-and then makes them livable, makes them meaningful. It provides an idealistic cadence, a taste of secularized heaven, of communal life, but it never challenges the naturalization of the unpolitical man "der unpolitische Mensch," the figure of the bourgeois, which appears as natural only as the result of the constitution of civil society as a realm severed from the state (233). More fundamentally, what Marx is diagnosing is a theologico-political apparatus of power that perpetuates itself by posing itself as necessary, naturalizing the general secular contradiction as an unsurpassable horizon of life itself. The function of mediation and the mediator is to stabilize external relations, rather than pushing the grammar toward dissolution. It offers a constrained participation, the necessary mechanism for the continual reproduction of the dirempted life. We might say that mediation is the modality in which transcendence is made livable and is lived.

This exceptional mediation arises not as a result of some anthropological givens but insofar as the secular state (the atheistic, democratic state in Marx's parlance) produces and maintains in its pure form what it presupposes - the existence of civil society and in it the "restricted individual, restricted to himself [auf sich beschränkten Individuums]" (229). It is not that depoliticized life has absconded from its existential duties (as Schmitt might have it), or that it has to be overcome and secured by sovereignty (as in Hobbes), but rather that civil society, "the sphere of egoism and of the bellum omnium contra omnes," is produced as such through a depoliticization that arises as the obverse side of the becoming autonomous 
of the state ${ }^{19}$ - a materialization of the Christian division of the terrestrial and the celestial into "the secular division" (220-221).

So, the figure of the bourgeois is hardly a natural figure. ${ }^{20}$ Its structure suggests something more. Parallel to Kantorowicz's thesis on the two bodies of the king, the figure or the bourgeois, despite all appearances, is itself not purely a secular figure but a political theological double: a profane and private individual that participates in the celestial species life as an exception, and only as an exception. That is, if with "the regicide, the gap closes between the king's two bodies," ${ }^{21}$ then perhaps a gap opens anew-less spectacularly, but no less tenaciously - in the unitary doublet of the egoistic individual/citizen. ${ }^{22}$ The task, Marx's essay suggests, is not to mistake this structure for freedom, and instead to see in it a secularization of Christian life in order to open the path to its abolition.

On this account, the modern secular state marks not the inauguration of political theology of immanence but rather reveals itself as a mechanism of transcendent mediation. The significance of this comes to light if we recall that in formulating the problematic of political theology, Schmitt diagnosed the nineteenth century as the moment of the shift into a metaphysics of immanence, against which his particular orientation of political theology of the sovereign exception that suspends the law is formulated. Schmitt formulates this transition as follows: "To the conception of God in the seventeenth and eighteenth centuries belongs the idea of his transcendence vis-à-vis the world, just as to that period's philosophy of state belongs the notion of the transcendence of the sovereign vis-a-vis the state. Everything in the nineteenth century was increasingly governed by conceptions of immanence. All the identities that recur in the political ideas and in the state doctrines of the nineteenth century rest on such conceptions of immanence." 23 Marx's account disturbs this genealogical narration by demonstrating that what Schmitt will call immanence is itself a transcendent apparatus of mediation. There has never been immanence, but only a polemical conflation of mediation with immanence perpetrated from the perspective of sovereign transcendence. Indeed, reading Marx alongside but against Schmitt, we might say that uncovering the operation of the secular state as one of transcendent mediation allows Marx to shed light on one half of a single katechonic mechanism, the other side of which is the sovereign exception. ${ }^{24}$ Transcendence as mediation and transcendence as sovereignty together form a single mechanism that prevents real immanence from irrupting, an immanence that would not be within the prevailing "order of the world [Weltordnung]." ${ }^{25}$ What Schmitt, whose position begins to appear as a kind of rearguard action, diagnoses as the indecisive 
hesitancy of a flailing liberalism and its apolitical bourgeois subjects, becomes, on this account, the internal counterpart to his theory of sovereign dictatorial exception. Immediate transcendence might see itself as radically distinct from its meditational counterpart, but in relation to real immanence, the two operate as an ensemble.

Political theology can be used as a way to delegitimate the secular in the direction of the Christian, or it can be rejected to uphold the legitimacy of the secular-both of these maneuvers, however, render invisible (if not actively dissimulate) the single mechanism that unites Christianity and secularism into one theologico-political space. ${ }^{26}$ In contrast to these prevailing positions, Marx diagnoses an apparatus of diremption, transcendence, and mediation operative in Christianity and, subsequently, materialized and secularized in the operations of the secular state. Mediation and transcendence do not belong exclusively on either side of the polemical divide between the Christian and the secular but are rather operative across it. Indeed, when Marx calls the existence of religion "a defect," religion in this instance should be understood as a name for a mechanismlike the state itself_-of recognition by means of an intermediary, an inhabitation of a specular relation with transcendence (217-218). Moreover, the solution to this so-called defect is not found in the secular state (which is why Marx is no secularist), but in the abolition of the very binary between the secular and the religious, in the abolition of the general secular contradiction that constitutes modernity. ${ }^{27}$ If Marx seeks the abolition of religion, he does so only as part of a more general abolition of secular power, the abolition of the order of the world in which the distinction between the secular and the religious is operative and dominant. ${ }^{28}$

What we have traced is a political theological diagnosis that undermines secular modernity's own self-authorizing and self-legitimating conceptual operations, without asserting either theological sources of legitimation and authority or sovereign-dictatorial ones. Marx's essay inaugurates a trajectory of thought that critiques the secular modern, by identifying its morphological and genetic entanglements with Christianity, disallowing them to claim each other as enemies, but without appealing to preexistent traditions-be they discursive, religious, or otherwise-as levers of critique. ${ }^{29} \mathrm{We}$ are faced with the question of what it might mean to challenge the secular frame without having recourse to a tradition or stable identity that might somehow be recovered from the violent impositions of political modernity. Indeed, by outlining the political theology of mediated transcendence, Marx asserts a structural analogy neither as a form of legitimation nor as a tragic impossibility but as an apparatus requiring delegitimation. For, it is the desire and drive for legitimation — of the modern age, the secular state, or a 
certain theological imaginary-that remains itself the problem. The drive to delegitimate the order of the world-along with its katechonic mechanisms of temporal distension, the temporalization and deferral that sustain the world across the political-theological domain-suggests a politicaltheological orientation toward dissolution and abolition rather than toward sovereignty or recovery. At hand is not preservation, recuperation, or reconstitution but the end of world and its determinate order. Rather than fearing lawlessness or anomia - as thinkers of order, Schmitt included, have always done-what must be challenged is the Christian-secular apparatus of the profanation and individuation of life and its ontological declaration that there is nothing but the self-enclosed individual, a position that legitimates, as Schmitt correctly pointed out, all of the punitive and salvific undertakings of theologians and politicians. ${ }^{30}$

Let me conclude with the conceptual element obviously kept in abeyance up to this point: human emancipation-the full emancipation Marx opposes to political emancipation-which would subvert rather than perpetuate the alienated, secularized structure of "a double life, a life in heaven and a life on earth" (220). For it is full human emancipation that indexes the breakdown of the general secular contradiction and the collapse of the order of the world-as opposed to political emancipation, which is "the last form of human emancipation within the prevailing Weltordnung" (221). In Marx's essay, the immanence that emerges with the collapse of the apparatus of mediated transcendence is correlated with the name of the human. But what assures us that what arises at the breakdown of the order of the world is the human, if not the dogmatic kernel of the specific secularization thesis that declares that at the end history stands the human in adequation of itself? If emancipation necessitates the dissolution of the world and its order, then how does the human remain, as it does in Marx's discourse, an obvious indexical and name? Perhaps, a genuine disruption of the political theological mechanism of dual transcendence, of mediation and sovereignty, might disclose a real immanence that no longer is allowed to carry the name of the human.

Much points toward the equivalence of immanence and the human in early Marx, and yet, there is a moment that points, however briefly, in a different direction. For, the necessity behind the breakdown of the order of the world, the delegitimation of the world as it is, arises not only because of the division between the state and the civil society but also because of an excess of dehumanization that occurs as the result of that structure. If, as Marx notes, "the rights of man" are nothing but those of civil society, there still remains the question of what is excluded even from this figure of "the restricted individual." The question of the human and political theology 
begins to be altered when we note that the figure of the proletariat emerges in the same issue of the Deutsch-Französische Jahrbücher, in the final passages of Marx's "Contribution to the Critique of Hegel's Philosophy of Right." There, it is presented as "a class of civil society which is not a class of civil society, a class which is the dissolution of all classes" - and, more fundamentally, "the total loss of humanity." This an immanent dissolution since it arises not from an ideal or a norm, but immediately from the truth of being: "When the proletariat proclaims the dissolution of the existing world order, it is only declaring the secret of its own existence, for it is the actual [faktische] dissolution of that order." The question is, then, if it is indeed a total loss of the world, its order, and the state-civil society divide that structures it, then on what grounds can that name, the name of the human, be retained? There is a movement from dehumanization that renders the human a profane being, to a further, total dehumanization of the wretched being. The split between the profane and the celestial is here complicated by this irrecuperable third. And if the secular is the worldly, then what undermines its coherence also might have to lie outside of the grammar of the human, which it has incessantly produced and reproduced. Yet Marx closes this trajectory as soon as he opens it, for the total loss of humanity is reinscribed into the normative horizon of the human: total loss leads to "the total redemption of humanity" and even more, it marks the proper opening onto the human, because this figure "can no longer lay claim to a historical title, but merely to a human one" (256). In light of the incorporation of the proletariat over the course of subsequent history into the fibers of civil society, a process that shows that one cannot retain the human while affirming total loss and deracination, it may be necessary to reopen the question of a radical immanence without the human. What would it mean to affirm the abolition of the prevailing order of the world from the perspective of that which is without tradition, from the position that does not belong except by and for delegitimation?

\section{Notes}

1. One of the more creative and original accounts that nevertheless positions political theology in this way is Victoria Kahn, The Future of Illusion: Political Theology and Early Modern Texts (Chicago: Chicago University Press, 2014).

2. For a general overview, see Yannik Thiem, "Schmittian Shadows and Contemporary Theological-Political Constellations," Social Research: An International Quarterly 80, no. 1 (2013): 1-32. Thiem does include Marx in the prehistory of political theology, albeit only cursorily.

3. Carl Schmitt, Political Theology: Four Chapters on the Concept of Sovereignty (Chicago: University of Chicago, 2005), 36. 
4. Jan Assmann, Herrschaft und Heil: Politische Theologie in Altägypten, Israel und Europa (München: Carl Hanser Verlag, 2000). To draw on this definition does not require subscribing to Assmann's specific theses on the price of monotheism, religio duplex, or the Mosaic distinction.

5. The most powerful critique of the legitimation of modernity in relation to the question of secularization is found in Kathleen Davis, Periodization and Sovereignty: How the Ideas of Feudalism and Secularization Govern the Politics of Time (Philadelphia: University of Pennsylvania Press, 2008), 1-20 and 77-102.

6. Karl Marx, Early Writings, trans. Rodney Livingstone and Gregor Benton (London: Penguin Books, 1992), 223. Hereafter cited in text by page number in parentheses. For the German version, see Karl Marx/Friedrich Engels Gesamtausgabe, Bd. 1.2, Werke, Artikel, Entwürfe: März 1843 bis August 1844 (Berlin: Dietz Verlag, 1982).

7. Roland Boer's multivolume work On Marxism and Theology offers a magisterial synthetic account of Marx’s (and Marxism's) relation to theology. For elements that are especially relevant to this essay, see Roland Boer, Criticism of Earth: On Marxism and Theology IV (Chicago: Haymarket Books, 2012), 69-125.

8. Gil Anidjar, "Secularism," Critical Inquiry 33, no. 1 (2006): 52-77.

9. For a powerful political-theoretical reconstruction of Marx's discussion on rights, recognition, and the ruses of political or ideal emancipation as it relates to the liberal state, see Wendy Brown, States of Injury: Power and Freedom in Late Modernity (Princeton, NJ: Princeton University Press, 1995), 100-114.

10. For one example of such a position, see Jürgen Habermas, An Awareness of What is Missing: Faith and Reason in a Post-secular Age (Cambridge: Polity, 2010); for a critical diagnosis of this gesture see Joan Wallach Scott, Sex and Secularism (Princeton, NJ: Princeton University Press, 2018).

11. On secularism not only as a normative power but also as a questioning power, one that repeatedly invests with significance the very boundary dividing the religious from the secular, see Hussein Ali Agrama, Questioning Secularism: Islam, Sovereignty, and the Rule of Law in Modern Egypt (Chicago: University of Chicago, 2012).

12. See, for example, Talal Asad, Genealogies of Religion: Discipline and Reasons of Power in Christianity and Islam (Baltimore, MD: Johns Hopkins University Press, 1993); Talal Asad, Formations of the Secular: Christianity, Islam, Modernity (Stanford, CA: Stanford University Press, 2003).

13. In this, I take Marx's claim to be fully in line with, for example, Asad's assessment that "the constitution of the modern state required the forcible redefinition of religion as belief, and of religious belief, sentiment, and identity as personal matters that belong to the new emerging space of private (as opposed to public) life" (Genealogies of Religion, 205).

14. Taking this into account, I do not think it is quite fair to say, as Saba Mahmood does, that Marx carries a "conception of religion as distorted belief." Religious Difference in a Secular Age: A Minority Report (Princeton, NJ: Princeton 
University Press, 2015), 15. On the one hand, Marx offers a critical analysis of the modern concept of religion as it is imbricated in the general secular contradiction, while on the other hand, as will be explored more fully in what follows, he elaborates a complex understanding of the relation between Christianity and the state centered on the interplay of transcendence and mediation.

15. Asad, Formations of the Secular, 1-17.

16. A version of this narration is recounted by Tomoko Masuzawa, The Invention of World Religions: Or, How European Universalism Was Preserved in the Language of Pluralism (Chicago: Chicago University Press, 2005).

17. For a complex analysis in which the position of the Muslim is produced as a problem by secular power in the contemporary moment, see Mayanthi L. Fernando, The Republic Unsettled: Muslim French and the Contradictions of Secularism (Durham, NC: Duke University Press, 2014). Fernando's book enacts in the contemporary moment for the Muslim French what Marx suggests doing in the case of nineteenth-century Jews: "Only the critique of political emancipation itself would constitute a definitive critique of the Jewish question itself and its true resolution into 'the general question of the age" (215). For a more complex genealogical history that complicates this point of convergence, see Gil Anidjar, The Jew, the Arab: A History of the Enemy (Stanford, CA: Stanford University Press, 2003).

18. Asad also formulates secularism as an apparatus of transcendent mediation (and not of immanence): "In an important sense, this transcendent mediation is secularism. Secularism . . . is an enactment by which a political medium (representation of citizenship) redefines and transcends particular and differentiating practices of the self that are articulated through class, gender, and religion" (Formations of the Secular, 5).

19. For an astute exploration of the way in which Marx's elaboration of the state as productive of civil society undermines the claim that civil society is the theater of all history, see Wendy Brown, Politics Out of History (Princeton, NJ: Princeton University Press, 2001), 88.

20. Wendy Brown notes that Marx is here offering "a political genealogy of the sovereign individual" (Politics, 112).

21. Rebecca Comay, Mourning Sickness: Hegel and the French Revolution (Stanford, CA: Stanford University Press, 2011), 39.

22. This then implies a different political theological trajectory of royal remains than the one centered on the flesh elaborated in Eric Santner, The Royal Remains: The People's Two Bodies and the Endgames of Sovereignty (Chicago: University of Chicago Press, 2011).

23. Schmitt, Political Theology, 49.

24. For a polemical analysis of Schmitt's deployment of the katechon, see Jacob Taubes, The Political Theology of Paul, trans. Dana Hollander (Stanford, CA: Stanford University Press, 2004), 97-113.

25. That Marx speaks of the order of the world is rendered invisible in the English rendering of Weltordnung as "scheme of things" (221). 
26. There is also, of course, the position, espoused first by Erik Peterson, that there is no possible Christian political theology; however, as Nicholas Heron makes clear, this is because it entails an explicitly Christian modality of power-liturgical power-and defends an altogether different (Christian) vision of politics. Nicholas Heron, Liturgical Power: Between Economic and Political Theology (New York: Fordham University Press, 2017).

27. For the way the secular and the religious are played off each other by philosophers and theologians, see Alex Dubilet, The Self-Emptying Subject: Kenosis and Immanence, Medieval to Modern (New York: Fordham University Press, 2018). On the way that this polemical divide is produced by secular power, see Agrama, Questioning Secularism.

28. It is worth noting that Marx states that this cannot be accomplished through a forceful abolition of religion by the state, through the kind of revolutionary secularism that is frequently attributed to Marx and the Marxist tradition. This is clear from his discussion of revolutionary moments, such as the French Revolution, in which "the state can and must proceed to the abolition of religion, to the destruction of religion" as part of a broader process in which "political life attempts to suppress its presupposition, civil society and its elements" (222). Yet, such attempts are self-subverting - for civil society is presupposed by the state as part of the general secular contradiction-leading first to an impossible permanent revolution against the state's own presuppositions, and then, in the end, in the restoration of all elements of civil society (222). This is the logic of the state in extremis, of the general secular contradiction taken to its political crescendo-but it does not inaugurate the dissolution of the order of the world. Marx's analysis here is another argument against understanding him as a radical secularist: for Marx, the task is neither for the state to manage religion as something privatized, nor for the state to abolish it by force. Rather, the task is the subversion of the entire foundational secular division between the state and civil society.

29. Recent critiques of the secular have frequently been imbricated with theorizations of alternative traditions. For Islam as discursive tradition in this line of thought, see Talal Asad, "The Idea of an Anthropology of Islam," Qui Parle 17, no. 2 (2000): 1-30; and Saba Mahmood, Politics of Piety: The Islamic Revival and the Feminist Subject (Princeton, NJ: Princeton University Press, 2005), 113-117.

30. See Carl Schmitt, The Concept of the Political, trans. George Schwab (Chicago: Chicago University Press, 1996), 64-65. 